\title{
Immobilization and stabilization of an endoxylanase from Bacillus subtilis (XynA) for xylooligosaccharides (XOs) production
}

\author{
Thais S.S. Milessi ${ }^{a}$, Willian Kopp ${ }^{a}$, Mayerlenis J. Rojas ${ }^{a}$, Anny Manrich ${ }^{\mathrm{a}, 1}$, \\ Alvaro Baptista-Neto ${ }^{b}$, Paulo W. Tardioli ${ }^{c}$, Roberto C. Giordano ${ }^{c}$, \\ Roberto Fernandez-Lafuente ${ }^{\mathrm{d}}$, Jose M. Guisan ${ }^{\mathrm{e}}$, Raquel L.C. Giordano ${ }^{\mathrm{c}, *}$ \\ a Graduate Program in Chemical Engineering, Federal University of São Carlos, PO Box 676, São Carlos, São Paulo, Brazil \\ b Bioprocess Bioengineering Department, FCF-UNESP, Rod. Araraquara-Jau, Km 01, Araraquara, São Paulo, Brazil \\ ${ }^{\text {c } C h e m i c a l ~ E n g i n e e r i n g ~ D e p a r t m e n t, ~ F e d e r a l ~ U n i v e r s i t y ~ o f ~ S a ̃ o ~ C a r l o s, ~ P O ~ B o x ~ 676, ~ Z C ~ 13565-905, ~ S a ̃ o ~ C a r l o s, ~ S a ̃ o ~ P a u l o, ~ B r a z i l ~}$ \\ ${ }^{\mathrm{d}}$ Biocatalysis Department, ICP-CSIC, CampusUAM-CSIC, Cantoblanco, ZC 28049 Madrid, Spain \\ e Institute of Catalysis, ICP-CSIC, Campus UAM-CSIC, Cantoblanco, ZC 28049 Madrid, Spain
}

\section{A R T I C L E I N F O}

\section{Article history:}

Received 5 March 2015

Received in revised form 26 May 2015

Accepted 29 May 2015

Available online 11 July 2015

\section{Keywords:}

B. subtilisendoxylanase

XynA

Immobilization

Stabilization

Xylooligosaccharides

\begin{abstract}
A B S T R A C T
Xylooligosaccharides (XOs) are small oligomers constituted by 2-10 units of xylan monomers, with important nutraceutical properties. They can be produced through hydrolysis of xylan catalyzed by an endoxylanase. The use of immobilized and stabilized enzymes may decrease the industrial process costs. In this study, XynA, a recombinant enzyme from B. subtilis, was immobilized in three different supports: agarose and chitosan activated with glyoxal groups and chitosan activated with glutaraldehyde. High immobilization yields were obtained, $100 \%$ for agarose-glyoxal and chitosan-glutaraldehyde, $82 \%$ for chitosan-glyoxal, with recovered activities of $42.7( \pm 1.3), 10.7 \pm 0.8$ and $53.6 \%( \pm 1.7)$, respectively. A great increase in the thermal stability of the enzyme (at $56^{\circ} \mathrm{C}, \mathrm{pH} 5.5$ ) was achieved for the glyoxal derivatives: 75 -fold for chitosan and 8600 -fold for agarose. The great thermal stability obtained to the derivative agarose-glyoxal can be explained by the enzyme immobilization through lysine residues located in unstable sites of the protein structure. The agarose-glyoxal derivative was tested in the production of XOs (X2, $\mathrm{X} 3$ and X4) from soluble and conventional birchwood xylan, reaching approximately $20 \%$ of conversion in $3 \mathrm{~h}$ and $23 \%$ in $24 \mathrm{~h}$, without the undesirable xylose production. After 10 cycles of hydrolysis, the conversion remained almost unchanged.
\end{abstract}

(c) 2015 Elsevier B.V. All rights reserved.

\section{Introduction}

Xylanases (beta-1,4-xylan xylanohydrolases; EC 3.2.1.8) catalyze the hydrolysis of beta-1,4-xylan, one of the major components of the plant cell walls and the second most abundant renewable polysaccharide in nature [1,2]. Nowadays, these enzymes are used mainly in the cellulose and paper industry, as additive in animal feed and for clarification of juices and vegetable oil extracts. Nevertheless, one important market for xylanases is for the production of xylooligosaccharides (XOs) [3-5]. XOs are oligomers constituted of xylan monomers linked by $\beta-(1-4)$ bonds, containing $2-10$ units of xylan $[5,6]$. They present nutraceutical

\footnotetext{
* Corresponding author. Tel.: +55 1633518708; fax: +55 1633518266

E-mail address: raquel@ufscar.br (R.L.C. Giordano).

1 Address: Embrapa Instrumentation, Rua XV de Novembro 1452, 13560-970 São Carlos, SP, Brazil.
}

properties that stimulate the growth of bifidobacteria in the human intestine, and can be used in low-calorie foods, as sweeteners [5]. Although XOs present many advantages in comparison with other oligosaccharides, production costs hinder their use $[4,6,7]$. The demand for XOs has grown in recent years. Besides, the availability of hemicellulose as a residue of second generation ethanol industry can further stimulate their production [5,8]. In addition, the use of xylanases to produce XOs is more advantageous than the chemical methods, due to the absence of undesirable by-products and the better quality of the XOs obtained [6,7].

Xylan is a complex heteropolymer, the main backbone constituted by $\beta$-D-xylopyranosyl units (xylose) linked by $(1-4)$ glycosidic bonds, that may be acetylated. It contains ramifications, different amounts of O-2 and/or O-3 linked arabinofuranosyl and O2 glucoropyranosil uronic acid. Its complete degradation requires the action of endo-xylanases (action in the middle of the backbone), $\beta$-xylosidase (to hydrolyse xylobiose, generating xylose) and debranching enzymes (to hydrolyse the side chains) [2]. For XOs 
production, it is important the use of an endoxylanase preparation free of $\beta$-xylosidase, since xylose is an undesirable byproduct [5]. Fungal xylanases extracts, which are the most used in industry, generally exhibit contamination by $\beta$-xylosidase. The use of a xylanase from B. subtilis (XynA), overexpressed in Escherichia coli [9], could prevent this problem since the enzyme was tested for XOs production with good results [8]. The XynA has 185 amino-acids and a weight of $22 \mathrm{kDa}[9,10]$. It is a monomeric enzyme whose three-dimensional structure has been elucidated [10].

Thermal stability is a key factor for the efficient and economical use of enzymes, and particularly of xylanases, in industrial processes $[2,3,11]$. The loss of catalytic activity at high temperatures is associated with changes on the enzyme native three-dimensional structure [12]. Many strategies have been studied in recent years to improve the thermal stability of enzymes, enabling their use in a growing number of processes. The search by new enzymes in thermophilic microorganisms [2,13], the modification of the enzyme structure by different techniques of molecular biology and the use of enzymes immobilization procedures are the main strategies to reach this goal [14].

In the molecular biology field, simulations of the threedimensional structure of enzymes (when available), identifying unstable zones in the proteins' structure, allow the prediction of the effects of amino-acid substitutions. This approach has yielded excellent results in recent years $[3,9,15]$. The use of direct evolution techniques has also shown that random changes in an unstable zone of a protein structure may also greatly enhance the thermal stability of some enzymes [11]. Molecular dynamics simulations allowed identifying unstable regions in the XynA structure [10]. In another study, the XynA structure was modified to increase its thermal stability, with good results [11].

On the other hand, the immobilization of an enzyme, when properly performed, may increase its thermal stability in hundreds or even thousands of times by different reasons (enzyme rigidification, creation of favorable environments or prevention of enzyme subunit dissociation), and may also improve other enzyme features, such as activity, selectivity, specificity or resistance to inhibitions [14,16-22]. The multipoint covalent attachment allows linking one enzyme molecule with an insoluble support through several bonds, decreasing its mobility and, consequently, increasing its thermal/operational stability [23-25]. The preferred reactions to achieve an intense multipoint covalent attachment involve the $\varepsilon$-amine groups from lysine residues in the protein and reactive groups in the carrier surface, mainly epoxy [26], and aldehydes $[15,27]$, in short space arms. In this method, the zone in the protein structure attached to the carrier loses its flexibility, becomes more rigid, and the linkage on different regions may imply modification of the enzyme structure and, consequently, of its catalytic properties $[15,27,28]$. In addition, the knowledge about the threedimensional protein structure permits to alter the orientation of the enzyme during its immobilization in heterofunctional carriers [29]. Other studies used site-directed mutagenesis to introduce cysteine residues in different zones of the enzyme surface to immobilize this enzyme through distinct zones, on heterofunctional carriers containing high density of reactive groups and low density of thiol groups $[15,28]$.

In a previous study [30], xylanase NS50014, a commercial complex, was immobilized in agarose and chitosan activated with glyoxal, epoxy and glutaraldehyde groups. The immobilization of xylanase XynA, a recombinant enzyme from B. subtilis whose threedimensional structure is known may provide a better elucidation of the results of the immobilization procedures. Xylanase from $B$. subtilis was reported, already in 1983, to have five lysines [31], which was further confirmed through other studies [9,10]. Therefore, in this work, the thermal stability of XynA was studied after its immobilization on agarose, or chitosan activated with glyoxal groups or chitosan activated with glutaraldehyde [32,33]. Chitosan is an aminated support that has been applied in many instances to the immobilization of different enzymes [34,35]. Glyoxyl-agarose has been described as a very inert support with great potential on enzyme stabilization via multipoint covalent attachment [27] and glutaraldehyde as a very versatile reagent for enzyme immobilization [36].

\section{Material and methods}

\subsection{Materials}

Recombinant xylanase from $B$. subtilis (XynA), with $193 \pm 5.9 \mathrm{UI} / \mathrm{mL}$ and $21 \pm 0.04 \mathrm{UI} / \mathrm{mg}$ protein, was kindly donated by Verdartis (Brazil), chitosan $85 \%$ deacetylation degree was purchased from Polymar Ind. Com. Imp. Exp. Ltda (Brazil). Sodium borohydride and birchwood xylan were purchased from SigmaAldrich SA (St. Louis, MO, USA). Agarose 6BCL was purchased from Amersham Pharmacia Biotech AB (Uppsala, Sweden). Other reagents had analytical grade.

\section{Methods}

\subsubsection{Preparation of glyoxal-agarose}

Commercial 6\% agarose gel was activated as previously described [32]. Agarose gel was suspended in water $(30 \mathrm{~mL} / 105 \mathrm{~g}$ of agarose) and kept in ice bath. $\mathrm{NaOH}$ solution $(1.7 \mathrm{~N})$, cold prepared and containing $28.5 \mathrm{mg} / \mathrm{mL}$ of sodium borohydride, was added to the agarose suspension $(50 \mathrm{~mL}$ of $\mathrm{NaOH}$ solution/105 $\mathrm{g}$ of agarose). Afterwards, glycidol was added dropwise $(36 \mathrm{~mL} / 105 \mathrm{~g}$ of agarose). The suspension was gently stirred at $25^{\circ} \mathrm{C}$ for $16 \mathrm{~h}$. The glyceryl agarose gel was then washed with water and filtered under vacuum. Next, the glyceryl-agarose was suspended in water ( $895 \mathrm{~mL} / 105 \mathrm{~g}$ of glyceryl-agarose), and sodium periodate was added ( $3.21 \mathrm{~g} / 105 \mathrm{~g}$ of glyceryl-agarose). The suspension was kept under gentle stirring for $2 \mathrm{~h}$ in order to maximize the number of glyoxal groups in the carrier. The number of glyoxal groups formed on the material surface was quantified by iodometry [32]. The glyoxal-agarose gel was washed and stored at $4{ }^{\circ} \mathrm{C}$.

\subsubsection{Preparation of chitosan gel}

Chitosan gel was prepared according to Silva et al. [37]. Chitosan powder $4 \%$ was dissolved in acetic acid $2 \%(\mathrm{v} / \mathrm{v})$ at room temperature. The resulting solution was heated to $50{ }^{\circ} \mathrm{C}$ and $\mathrm{KOH} 0.5 \mathrm{M}$ was added in the ratio $3: 2(\mathrm{v} / \mathrm{v})(\mathrm{KOH}$ solution/chitosan solution). Next, the solution was stirred during $1 \mathrm{~h}$, to coagulate chitosan. After the procedure, the gel obtained was washed with distilled water and stored until use.

\subsubsection{Chitosan-glyoxal activation}

Chitosan-glyoxal was prepared by mixing the gel under stirring with an aqueous solution containing $\mathrm{NaOH} 2 \mathrm{M}$ and $\mathrm{NaBH}_{4} 0.12 \mathrm{M}$ [38], in ice bath. Then, $1 \mathrm{~mL}$ of epichlorohydrin per gram of gel was added and kept under mechanical stirring for $18 \mathrm{~h}$. Following, the epoxy groups formed on the chitosan surface were hydrolyzed to glyceryl groups by incubation in sulfuric acid $0.5 \mathrm{M}(1 \mathrm{~h})$. In the next step, chitosan-diol gel was reacted with $1 \mathrm{~mL}$ of $0.1 \mathrm{M} \mathrm{NaIO}_{4}$ solution per gram of gel for $2 \mathrm{~h}$ at room temperature [32]. Afterwards, it was washed with an excess of distilled water until neutrality. The number of glyoxal groups formed in the material surface was quantified by iodometry [32]. Between each step, the carrier was filtered 
and washed thoroughly with distilled water. After the procedure, the chitosan-glyoxal gel was stored until use.

\subsubsection{Chitosan-glutaraldehyde activation}

Chitosan was activated with glutaraldehyde following a methodology adapted from Budriene et al. [39]. The process was carried out by adding $5 \%(\mathrm{v} / \mathrm{v})$ glutaraldehyde to $10 \mathrm{~g}$ of chitosan gel $(10 \% \mathrm{w} / \mathrm{v})$ at room temperature and $\mathrm{pH} 7.0$ (phosphate buffer $100 \mathrm{mM}$ ). After $60 \mathrm{~min}$, the gel was washed with Milli-Q water and then used for enzyme immobilization.

\subsection{Enzyme dialysis}

Xylanase from $B$. subtilis (XynA), crude extract, was dialyzed using a $14 \mathrm{kDA}$ cellulose membrane, at $4{ }^{\circ} \mathrm{C}, \mathrm{pH} 7$, in the ratio $1 / 100$ between enzyme extract and ultrapure water (type 1), during $24 \mathrm{~h}$. The ultrapure water was replaced each $8 \mathrm{~h}$.

\subsubsection{Immobilization of XynA on different supports}

Xylanase immobilization procedures were initially performed for an enzyme load of $105.0 \mathrm{UI} / \mathrm{g}$ of support, for the three prepared supports. For the agarose-glyoxal support, the immobilization was also performed for the enzyme loads: $3.93,39.3$ and $393.0 \mathrm{UI} / \mathrm{g}$ of support. For all immobilization procedures, the carrier was suspended in an enzyme solution in $1: 10 V_{\text {gel }} / V_{\text {solution }}$ ratio. The immobilizations on glyoxal-agarose and chitosan-glyoxal were carried out at $\mathrm{pH} 10.0$ (sodium bicarbonate buffer $100 \mathrm{mM}$ ). The suspension was kept at $25^{\circ} \mathrm{C}$ under constant stirring, samples were taken at periodic intervals and enzyme activity and total protein were measured. The remaining aldehyde groups were reduced using sodium borohydride $\left(0.5 \mathrm{mg} / \mathrm{ml}, 4^{\circ} \mathrm{C}, 30 \mathrm{~min}\right)$ and the Schiff bases were converted to very stable secondary amino bonds. The immobilization in chitosan-glutaraldehyde was performed at $\mathrm{pH}$ 7.0 in $100 \mathrm{mM}$ phosphate buffer [36] at $25^{\circ} \mathrm{C}$ under constant stirring. Samples were taken at periodic intervals and enzyme activity and total protein were measured. After the immobilization procedures, the derivatives were extensively washed with $50 \mathrm{mM}$ citrate buffer $\mathrm{pH} 4.8$ and stored until use.

The immobilization parameters were calculated according to Adriano et al. [40]. They were defined as immobilization yield (IY) and recovered activity (RA). IY is the ratio between the units of immobilized enzyme (units of enzyme disappeared in the supernatant, theoretically immobilized) and the units of enzyme offered to immobilize. RA is the ratio between the measured immobilized enzyme activity and the theoretically immobilized activity. A blank assay was always run to take into account possible inactivation of the enzyme under immobilization conditions. The immobilization yield was calculated by measuring enzyme activities in the blank solution and in the supernatant. The percentage of enzyme not immobilized was calculated dividing the remaining activity in the supernatant by the enzyme activity measured in the blank, taking into account the dilution due to the addition of gel ( $9 \mathrm{~mL}$ of enzyme solution $+1 \mathrm{~g}$ of gel). Because the offered enzyme load was known, the number of enzyme units theoretically immobilized per gram of gel (At theoretically immobilized) could be calculated.

After finishing the immobilization, the apparent gel activity $A t_{\text {app }}$ (enzyme units, $\mathrm{Ug}_{\text {gel }}{ }^{-1}$ ) was measured and compared with the theoretically immobilized. The recovered activity was then calculated as $A t_{\text {app }}\left(U g_{g e l}{ }^{-1}\right) / A t_{\text {theoretically immobilized }}\left(U g_{\text {gel }}{ }^{-1}\right)$.

\subsubsection{Determination of total protein}

Protein concentrations were determined through the Bradford [41] method, using BSA as standard.

\subsubsection{Determination of xylanase activity}

Xylanolytic activity was determined according to IUPAC [42] by calculating the initial velocity of xylan hydrolysis catalyzed by a known amount of enzyme. The standard substrate was birchwood xylan $(1 \%(\mathrm{w} / \mathrm{v}))$ in $50 \mathrm{mM}$ citrate buffer $\mathrm{pH}$ 5.5. Free or immobilized enzyme were added to the reaction medium and incubated at $50^{\circ} \mathrm{C}$ for 10 min under mechanical stirring. Aliquots were withdrawn each $2 \mathrm{~min}$, and the released reducing sugars were quantified by the dinitrosalicylic acid method (DNS) [43]. One unit of activity (UI) was defined as the amount of enzyme required to release $1 \mu \mathrm{mol}$ of xylose per minute under the tested conditions.

\subsubsection{Thermal inactivation of XynA}

Assays were performed at $56^{\circ} \mathrm{C}$. Soluble enzyme and suspensions of derivatives were incubated in $50 \mathrm{mM}$ citrate buffer $\mathrm{pH} 5.5$. Aliquots were withdrawn periodically for quantification of residual enzymatic activity to estimate the half-life time.

\subsubsection{Enzymatic xylan hydrolysis}

Xylan hydrolysis was studied using soluble XynA and the glyoxal-agarose derivative. The process was carried out using the soluble fraction of the xylan or the conventional commercial xylan. The conventional xylan consisted of commercial birchwood xylan prepared in $50 \mathrm{mM}$ citrate buffer, $\mathrm{pH} 5.5$, composed by both soluble and insoluble xylan fractions. The soluble xylan, on the other hand, consisted of only soluble fraction obtained by a centrifugation step. The soluble fraction was obtained by adding $4 \mathrm{~g}$ of commercial birchwood xylan in $100 \mathrm{~mL}$ of $50 \mathrm{mM}$ citrate buffer, pH 5.5 at $50^{\circ} \mathrm{C}$. After $1 \mathrm{~h}$ under stirring, the solution was centrifuged for $20 \mathrm{~min}$ at $9500 \mathrm{~g}$ and $5{ }^{\circ} \mathrm{C}$. The supernatant was then recovered for further use. The mass of non-soluble xylan was then calculated by dry weight, and it was $67 \%$ of the initial mass. Therefore, the soluble xylan fraction in $4 \mathrm{~g}$ was $1.3 \mathrm{~g}(13 \mathrm{mg} / \mathrm{mL})$. Conventional xylan substrate corresponded to $8.7 \mathrm{mg} / \mathrm{mL}$ of insoluble and $4.3 \mathrm{mg} / \mathrm{mL}$ of soluble xylan. For the hydrolysis assays, soluble or conventional birchwood xylan were prepared in $50 \mathrm{mM}$ citrate buffer $\mathrm{pH} 5.5$, at the concentration of $13 \mathrm{mg} / \mathrm{mL}$. $1.95 \mathrm{UI} / \mathrm{mL}$ of enzyme (free or immobilized) were added to these substrates. The reaction was conducted at $50^{\circ} \mathrm{C}$ under mechanical stirring for $24 \mathrm{~h}$. Samples were withdrawn and the produced XOs were quantified by HPLC, while reducing sugars were analyzed by the DNS method.

\subsection{XOs quantification}

Xyloolygomers (XOs) were quantified by high performance liquid chromatography (HPLC) (Waters, USA) equipped with a Waters Sugar-Pak I column $(300 \times 6.5 \mathrm{~mm})$ coupled to a detector of refractive index, RID (W410 Waters). Milli-Q water was used as eluent at a flow rate of $0.5 \mathrm{~mL} \mathrm{~min}^{-1}$. The column temperature was $80^{\circ} \mathrm{C}$ and the injected volume was $20 \mu \mathrm{L}$. Before the analysis, the samples were filtered using a $0.22 \mu \mathrm{m}$ filter.

\subsection{Xylan conversion}

After XOs quantification, the concentration of the xylan consumed for the production of two, three or four monomeric units was calculated using stoichiometric factors $\left(f x_{2}, f x_{3}\right.$ and $\left.f x_{4}\right)$ determined as indicated following Eqs. (1-3).

$$
\begin{aligned}
& \left(\mathrm{C}_{5} \mathrm{H}_{8} \mathrm{O}_{4}\right)_{n}(132.11 \mathrm{~g} / \mathrm{mol})+\left(\frac{n}{2}-1\right) \mathrm{H}_{2} \mathrm{O} \\
& \rightarrow \frac{n}{2} \text { xylobiose }(282.4 \mathrm{~g} / \mathrm{mol})
\end{aligned}
$$


A)

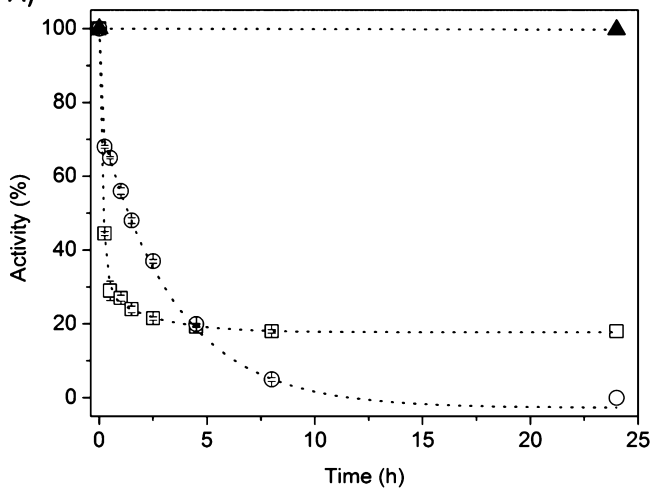

B)

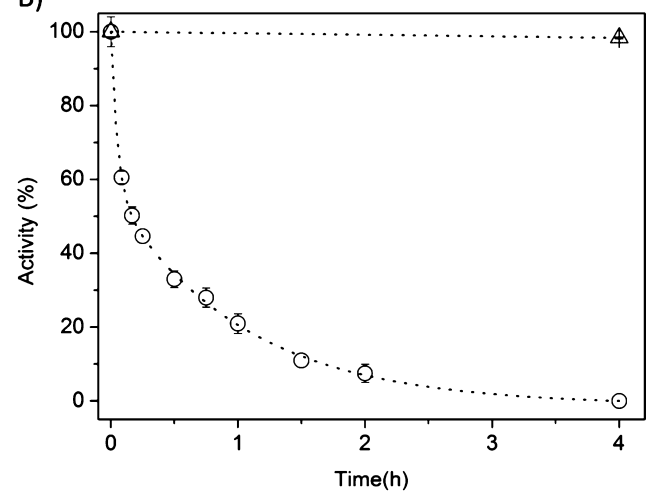




Immobilization conditions: $100 \mathrm{mM}$ phosphate buffer $\mathrm{pH} 7.0$ at $25^{\circ} \mathrm{C}$. Error bars: s.d. of triplicates.

$$
\begin{aligned}
& \left(\mathrm{C}_{5} \mathrm{H}_{8} \mathrm{O}_{4}\right)_{n}(132.11 \mathrm{~g} / \mathrm{mol})+\left(\frac{n}{3}-1\right) \mathrm{H}_{2} \mathrm{O} \\
& \rightarrow \frac{n}{3} \text { xylobiose }(414.40 \mathrm{~g} / \mathrm{mol})
\end{aligned}
$$

$$
\begin{aligned}
& \left(\mathrm{C}_{5} \mathrm{H}_{8} \mathrm{O}_{4}\right)_{n}(132.11 \mathrm{~g} / \mathrm{mol})+\left(\frac{n}{4}-1\right) \mathrm{H}_{2} \mathrm{O} \\
& \rightarrow \frac{n}{4} \text { xylobiose }(546.47 \mathrm{~g} / \mathrm{mol})
\end{aligned}
$$

$$
\begin{aligned}
& f x_{2}=\frac{132.11 \times 2}{282.24}=0.936, f x_{3}=\frac{132.11 \times 3}{414.40}=0.956, \text { and } \\
& f x_{4}=\frac{132.11 \times 4}{546.47}=0.966
\end{aligned}
$$

and

xylan conversion $=\frac{f x_{2} \times C_{x 2}+f x_{3} \times C_{x 3}+f x_{4} \times C_{x 4}}{C_{\text {xylan }}^{\text {initial }}}$

where $C=$ concentration $(\mathrm{mg} / \mathrm{mL})$.

\subsubsection{Operational stability assays}

Recycle assays were carried out using $6 \mathrm{~mL}$ of soluble birchwood xylan $(15 \mathrm{mg} / \mathrm{mL})$ in $50 \mathrm{mM}$ citrate buffer $(\mathrm{pH} 5.5)$ at $50^{\circ} \mathrm{C}$ under constant stirring. The glyoxal-agarose derivative was offered in a proportion of $150 \mathrm{UI} / \mathrm{g}$ of xylan and each cycle endured $3 \mathrm{~h}$. The derivative was easily recovered and separated from the products by filtration. Between each reaction cycle, the recovered derivative was washed twice with $50 \mathrm{mM}$ citrate buffer $(\mathrm{pH} 5.5)$ at $25^{\circ} \mathrm{C}$, and then a fresh substrate was added for a new cycle, successively for 10 times.

\section{Results and discussion}

\subsection{Immobilization of XynA}

Immobilization of the enzyme was carried out in agarose activated with glyoxal groups (agarose-glyoxal), chitosan activated with glyoxal groups (chitosan-glyoxal) and chitosan activated with glutaraldehyde (chitosan-glutaraldehyde), initially with an enzyme load of $105 \mathrm{UI} / g_{\text {wet support }}\left(5 \mathrm{mg}\right.$ of protein $/ g_{\text {wet support }}$ ). The chitosan-glyoxal support presents a high density of glyoxal groups on its surface, like the agarose-glyoxal one, but with a different internal morphology [30] and a layer of cationic groups beneath the aldehyde groups. On the other hand, the activation of chitosan with glutaraldehyde at $\mathrm{pH} 7$ and the immobilization using sodium phosphate $100 \mathrm{mM}$ may favor that the immobilization first step would be via a covalent bond between the support and the most reactive amine group (very likely, the amine terminal group of the protein). At this $\mathrm{pH}$, the lysine groups are not reactive [30]. Therefore, the different immobilization protocols, for different supports, may produce quite distinct results.

Activation of agarose $6 \%$ (with glycidol) and chitosan $4 \%$ (with epichlorohydrin) generated, respectively, 82 and $184 \mu \mathrm{mol}$ of glyoxal groups per gram of wet material. The higher number of aldehyde groups obtained for chitosan when compared with agarose is due to the fact that this material contains not only hydroxyl reactive groups, but also amine groups available for activation with glycidol. This phenomenon was already observed by Rodrigues et al. [33], who reported values for the activation protocols glycidol-agarose and epichlorohydrin-chitosan that agree with the ones obtained in this work.

Fig. 1 shows the XynA immobilization kinetics on agarose-glyoxal and chitosan-glyoxal (Fig. 1a) and on chitosanglutaraldehyde (Fig. 1b) for the enzyme load of $105.0 \mathrm{UI} / \mathrm{g}_{\text {wet support }}$. The soluble enzyme (XynA) preserved $100 \%$ of activity under incubation in the immobilization conditions for all the immobilization protocols. After $8 \mathrm{~h}$ of incubation, $100 \%$ of the enzyme was immobilized on agarose-glyoxal and $82 \%$ on chitosan-glyoxal, even though the amount of groups was higher in the last case. These excellent results of immobilization yield were unexpected, bearing in mind the low concentration of lysine residues on the XynA surface. The immobilization process on glyoxal-activated carriers requires the formation of at least two simultaneous bonds (reversible Schiff bases) between the glyoxal groups and the $\varepsilon-\mathrm{NH}_{2}$ of the lysine residues [44]. Therefore, at first glance, the low number of lysine residues might prevent an efficient immobilization, as already observed by Manrich et al. [30], for commercial xylanase. Indeed, Manrich et al. [30] had to make a chemical modification of the enzyme, by reaction with ethylenediamine, to add additional amine groups to the enzyme surface in order to make possible the multipoint immobilization.

The analysis of the three-dimensional structure of the enzyme shown in Fig. 2 [9,11], may help in understanding these results: the particular location of the lysine residues on the enzyme surface may have collaborate in the immobilization process, since at least three of them are in the same plane, making possible the multipoint immobilization through this area. The immobilization assay for chitosan-glyoxal was extended to $24 \mathrm{~h}$, but no further increase in the immobilization yield was observed. The lower IY of the enzyme 
Table 1

Influence of the enzyme load in the immobilization parameters of XynA in glyoxal-agarose.

\begin{tabular}{|c|c|c|c|c|}
\hline \multirow[t]{2}{*}{ Immobilization parameter } & \multicolumn{4}{|c|}{ Enzyme load $\left(\mathrm{UI} / \mathrm{g}_{\text {gel }}\right)^{\mathrm{a}}$} \\
\hline & 3.93 & 39.3 & $105.0^{* \mathrm{e}}$ & 393.4 \\
\hline $\mathrm{YI}(\%)^{\mathrm{b}}$ & 100 & 100 & 100 & 74.0 \\
\hline Atgel $\left(\mathrm{UI} / \mathrm{g}_{\mathrm{gel}}\right)^{c}$ & $1.7 \pm 0.1$ & $16.3 \pm 1.7$ & $44.8 \pm 3.9$ & $19.5 \pm 1.3$ \\
\hline $\mathrm{RA}(\%)^{\mathrm{d}}$ & $43.1 \pm 2.7$ & $41.3 \pm 4.9$ & $42.7 \pm 1.3$ & $6.7 \pm 0.4$ \\
\hline
\end{tabular}

a Enzyme load $\left(\mathrm{UI} / \mathrm{g}_{\mathrm{gel}}\right)=$ units of enzyme offered for immobilization;

b $\mathrm{YI}(\%)=$ immobilization yield;

c RA (\%) = recovered activity;

d Atgel $\left(\mathrm{UI} / \mathrm{g}_{\mathrm{gel}}\right)=$ measured activity in the support after enzyme immobilization;

e First experiment.

in chitosan-glyoxal, after activation with epichlorohydrin, was also reported by Rodrigues et al. [33], for the immobilization of Candida antarctica lipase B (CALB). The maximum IY obtained was $17 \%$, after $72 \mathrm{~h}$ of immobilization. According to the authors, a possible explanation could be a decrease in the mean porous diameter of chitosan after activation with epichlorohydrin. If that occurred, the enzyme could not reach most of the support surface. This explanation agrees with the results presented here, where IY of $82 \%$ was obtained for XynA, that has 183 amino-acids residues and 22 KDa [9,10]. CALB has 317 amino-acid residues, with a molar mass of $33 \mathrm{KDa}$ [45]. Of course, a higher molar mass implies a smaller reachable surface on chitosan after activation with epichlorohydrin. On the other hand, our values of recovery activities for these two derivatives were in an opposite direction: the RA for the chitosan-glyoxal derivative was higher than the observed for the agarose-glyoxal one.

The RA values for agarose-glyoxal-XynA and chitosan-glyoxalXynA were $42.7 \pm 1.3$ and $53.6 \pm 1.7 \%$, respectively. There are two hypotheses to explain this loss of app. $50 \%$ of enzyme activity: mass transfer delays or a modification of the enzyme structure caused by its multipoint immobilization (i.e. inherent reaction rates lower than the intrinsic ones). The low enzyme load within the support that was used here, $5 \mathrm{mg}$ protein $/ \mathrm{g}_{\text {gel }}$, suggested that the second premise would be more likely predominant. The higher RA for the chitosan-glyoxal derivative also indicates that the most probable explanation for the loss of activity would be enzyme distortion. Higher diffusion effects in agarose than in chitosan are not expected. If mass transport effects were masking the measured recovered activities, this effect had to be stronger for chitosan, the support with the smaller diameter [46], which, in consequence, would present lower recovered activity than the agarose-glyoxal one. Furthermore, the internal structure of agarose is reported to favor the formation of multipoint bonds [14]. Consequently, if enzyme distortion were the predominant cause for the loss of activity, a lower RA for agarose than for chitosan-glyoxal would be expected. In order to confirm these hypotheses, new immobilization experiments were conducted aiming at to check the presence of diffusion effects. Different enzyme loads were tested, lower and higher than the first one tested. If the recovered activity for a lower enzyme load were the same than the one obtained for the first tested load, then the measured initial velocity of the reaction for the immobilized enzyme would be the inherent reaction rate. Additionally, if the inherent reaction rate were indeed lower than the intrinsic one, it would mean that a great number of enzyme-substrate bonds were effectively established. Table 1 shows the results of the immobilization parameters for all the enzyme loads tested to immobilize XynA on agarose-glyoxal. It can be noticed from these results that there is no change in the recovered activity of the enzyme up to the enzyme load of $105 \mathrm{UI} / \mathrm{g}_{\text {gel }}$. Then, at least up to this enzyme load, the loss of activity after immobilization must be caused by distortion of the structure due the

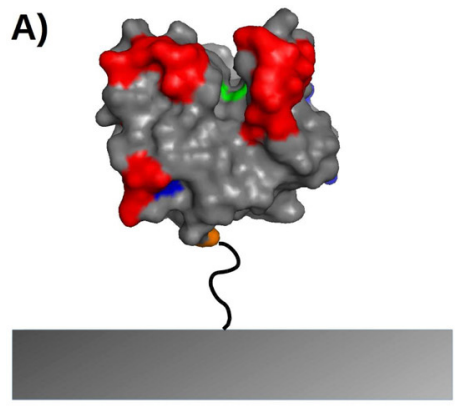

C)

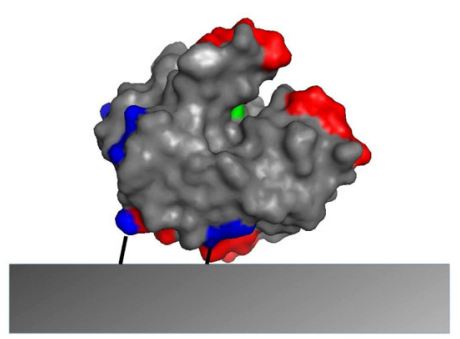

B)

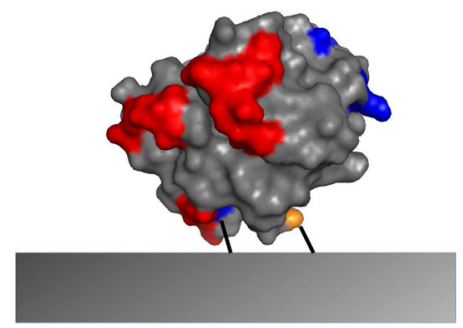

D)

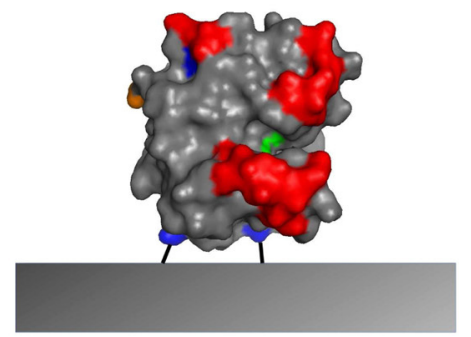



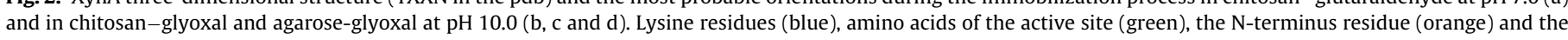
regions of low stability in the protein structure (red). 
A)


B)

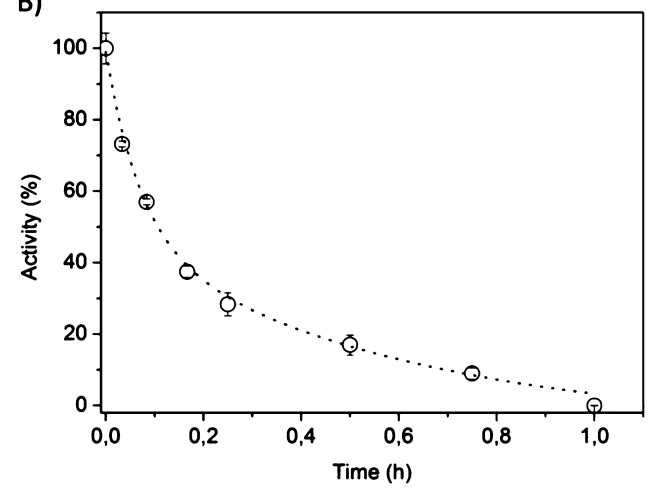

D)

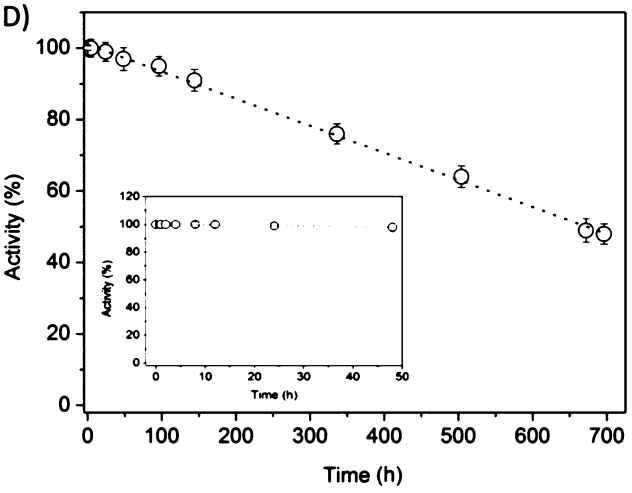




glyoxal-XynA derivative $\left(D_{0}=44.84 \pm 3.7 \mathrm{UI} / \mathrm{ggel}\right)$. Error bars: s.d. of triplicates.

formation of multipoint bonds, which reinforces the expectation of a great increase in the enzyme stability after immobilization. On the other hand, for an offered enzyme load of $393.3 \mathrm{UI} / \mathrm{g}_{\text {gel }}$, a decrease in recovered activity was observed, indicating that, in this case, mass transfer resistance may be contributing to the decrease in the apparent reaction velocity. The agarose-glyoxal derivative chosen for further studies was the one with the highest activity and without significant mass transfer limitations, with $105 \mathrm{UI} / \mathrm{g}_{\text {gel }}$.

Fig. 1b shows the results for the immobilization of XynA in chitosan-glutaraldehyde. IY of $100 \%$ was obtained after $4 \mathrm{~h}$ of incubation. The condition used in this experiment (phosphate buffer $100 \mathrm{mM} \mathrm{pH} \mathrm{7.0)} \mathrm{avoids} \mathrm{ionic} \mathrm{adsorption} \mathrm{of} \mathrm{the} \mathrm{enzyme} \mathrm{and} \mathrm{favors}$ covalent immobilization through the most reactive protein group of the protein (very likely the N-terminal group, which in Fig. 2 is shown to be fully exposed). Only one Lys group seems to be in the same plane of this amino group. The recovered activity obtained for XynA immobilization on chitosan-glutaraldehyde was only $10.7 \pm 0.8 \%$. Under the immobilization conditions ( $\mathrm{pH} 7)$, the first covalent linkage of the enzyme on the support should be by the most reactive amino group, and this should be the $\mathrm{N}$-terminal [36]. Fig. 2 shows that only one Lys group is located in the same plane of the enzyme $\mathrm{N}$-terminal group. This fact, in association with the immobilization conditions makes multipoint immobilization unlikely, once at $\mathrm{pH} 7$, the reactivity of the amino groups in Lys residues is reduced. Therefore, the decrease of the enzyme activity probably was not caused by the formation of multiple bonds between the enzyme and the support and other explanation needs to be found for this drop in activity. The most likely explanation is that the terminal amino group of this enzyme has an important function in the preservation of xylanases' three-dimensional conformation [10]. Moreover, the support surface is not inert. The reactive groups have ionic and hydrophobic groups, which can produce some interactions after enzyme immobilization [36]. Chitosan also have some hydrophobic character. Yet, glutaraldehyde is a very reactive substance and may react in different ways depending on the gel structure, immobilization conditions and reactive groups in the enzyme surface [36]. Accordingly, values of RA from 21 to $86 \%$ were reported by Manrich et al. [30] for the commercial xylanase NS50014 immobilized on chitosan activated with glutaraldehyde, using different coagulant agents for the gel formation and different conditions for the immobilization reaction.

\subsection{XynA thermal stability}

Xylanases with high thermal stability are necessary in many industrial processes, especially for XOs production. High temperatures lead to higher reaction velocities and, consequently, lower reactor volume. Besides, they may be useful to increase xylan solubility and to prevent microbial contamination [47]. The three derivatives of XynA obtained here were tested for their thermal stability and compared with the free enzyme.

Fig. 3a shows the residual activity of the soluble XynA under incubation at $56^{\circ} \mathrm{C}$ in $50 \mathrm{mM}$ citrate buffer $\mathrm{pH}$ 5.5. Under these conditions, the free (soluble) enzyme lost $100 \%$ of its catalytic activity after only $30 \mathrm{~min}$, with a half-life of only $4.7 \mathrm{~min}$. The more usual condition for XOs production is pH 5.5 and between 50 and $55^{\circ} \mathrm{C}$ $[5,8]$. The temperature of maximum activity for $\mathrm{XynA}$ is $58^{\circ} \mathrm{C}[10]$. Fig. $3 \mathrm{~b}$ indicates that chitosan-glutaraldehyde-XynA, as expected, presents a deactivation profile only slightly slower than the free enzyme's. It was necessary only $60 \mathrm{~min}$ for this derivative to lose all catalytic activity, with a calculated half-life of $6.4 \mathrm{~min}$, only 1.4 times higher than that the free enzyme's.

Thermal inactivation profiles of the glyoxal derivatives, chitosan and agarose glyoxal-XynA, respectively, are shown in Fig. 3c and $\mathrm{d}$. As expected, there was a great increase in the half-lives of both glyoxal derivatives, suggesting the formation of multipoint 

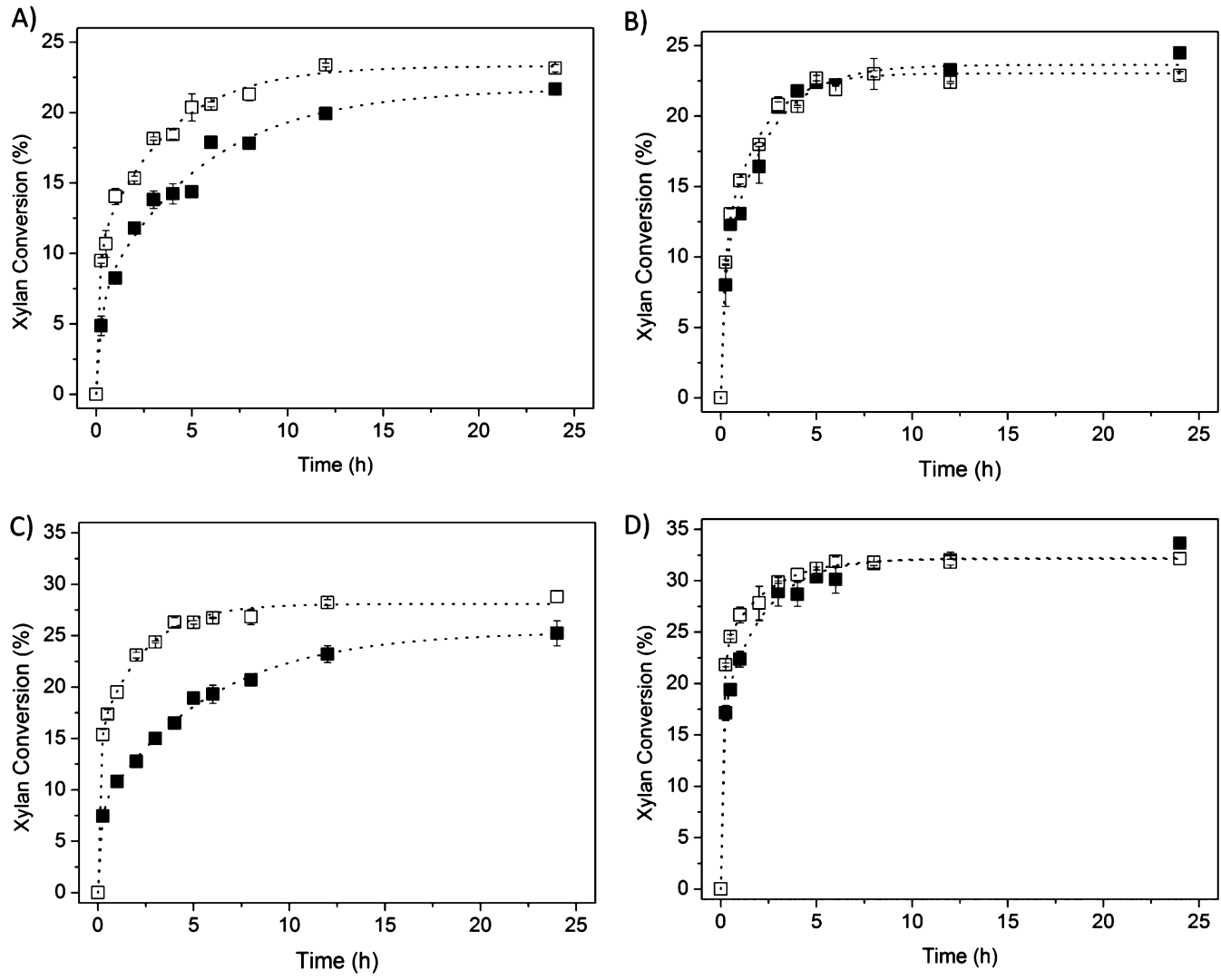

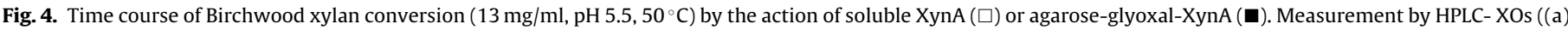
conventional xylan; (b) soluble xylan) and reducing sugars ((c) conventional xylan; (d) soluble xylan). Error bars: s.d. of triplicates.

bonds between enzyme and the support. Fig. 3c shows that the chitosan-glyoxal-XynA preserved $21 \%$ of its initial activity after $30 \mathrm{~h}$ of incubation under the test conditions. The half-life of the chitosanglyoxal-XynA was $357 \mathrm{~min}(5.95 \mathrm{~h}), 75$-fold more stable than the soluble enzyme, and higher than the best-reported stability results in the literature for immobilized xylanase $[30,48]$.

The thermal stability of the agarose-glyoxal-XynA, in turn, was remarkable. Results showed in Fig. 3d provide a half-life value of $40,385 \mathrm{~min}(673 \mathrm{~h})$ for this derivative, 8600 -fold more stable than the soluble enzyme and 113-fold more stable than the chitosanglyoxal derivative. To the best of our knowledge, this is the most significant result obtained until now for an immobilized xylanase. This result was unexpected, in view of the low number of lysines on the XynA surface. The formation of several bonds between enzyme and the support is necessary to increase the thermal stability of enzymes, and particularly for xylanase $[7,30,47,48]$, but XynA has only three lysines in the same plane. Consequently, this is the maximum number of attachments that may be achieved.

Nevertheless, the location of these lysines on the surface of the enzyme is noteworthy (Fig. 2). It is possible to notice that there are two possibilities for the link of three groups to the support: one plane includes three Lys and another plane covers two Lys and the $\mathrm{N}$-terminal group. Moreover, the lysine residues are located in the regions described as the most unstable regions of the enzyme [10]. Four of them are close to each other and located in unstable regions of the enzyme. Besides, XynA has a low molar mass, what may increase the effect of tri-points bonds between enzyme and support. In this particular case, then, the specific location of the two and/or three bonds may have been enough to decrease drastically the enzyme flexibility [49]. Therefore, the immobilization of XynA through these lysines was a well-succeeded strategy for the stabilization of the enzyme, in a much simpler approach than using molecular biology techniques to change amino acids in the protein zones of low structural stability [11].

The lower stability of the chitosan-glyoxal-XynA derivative when compared with the agarose-glyoxal one can be explained by the morphological differences between these materials $[33,50]$ or by the inertness of the glyoxal-agarose surface versus the cationic and hydrophobic groups presented in chitosan. However, another important feature of the immobilization system is the morphological characteristic of the carrier. The agarose fiber presents a planar and rigid structure that favors the linkage of the enzyme over the fiber, in two dimensions [12]. This morphological characteristic in conjunction with the high density of glyoxal groups in a short space-arm is the great differential that made this carrier one of the most successful for enzyme immobilization. The chitosan carriers, in turn, present a more malleable and shapeless structure, which may allow the fiber adapting to the enzyme structure during the immobilization process instead of inducing changes in the enzyme, with a lower increase in the enzyme thermal stability. The amino groups present in the chitosan fiber also interact with partially unfolded enzyme structures at high temperatures, accelerating the deactivation process [12].

\subsection{Xylan hydrolysis by soluble and immobilized XynA}

The hemicellulose fraction of biomass is currently underutilized as a raw material. Taking into account the concept of a biorefinery, the development of new processes for the obtainment of high value-added products from hemicellulose is a matter of increasing importance [51]. The use of residual hemicellulose for XOs production may be a good option for adding value to residual biomass. The agarose-glyoxal-XynA derivative obtained in this study seems to be a promising catalyst for the industrial 
Table 2


$\left.\mathrm{pH} 5.5,50^{\circ} \mathrm{C}\right)$ catalyzed by soluble XynA $(1.95 \mathrm{UI} / \mathrm{mL})$.

\begin{tabular}{|c|c|c|c|c|c|c|c|c|c|c|c|c|c|c|c|c|}
\hline \multirow[t]{2}{*}{ Time $(\mathrm{h})$} & \multicolumn{8}{|c|}{ Conventional xylan $(\mathrm{mg} / \mathrm{mL})$} & \multicolumn{8}{|c|}{ Soluble xylan $(\mathrm{mg} / \mathrm{mL})$} \\
\hline & $\mathrm{X} 7+$ & $\mathrm{X} 6$ & $\mathrm{X} 5$ & $\mathrm{X} 4$ & $\mathrm{X} 3$ & $\mathrm{X} 2$ & $\mathrm{X} 1$ & Total XOs & $\mathrm{X} 7+$ & $\mathrm{X} 6$ & $\mathrm{X} 5$ & $\mathrm{X} 4$ & X3 & $\mathrm{X} 2$ & $\mathrm{X} 1$ & Total XOs \\
\hline 1 & 11.1 & 0.00 & 0.00 & 0.47 & 1.14 & 0.27 & 0.00 & 1.9 & 10.9 & 0.00 & 0.00 & 0.54 & 1.17 & 0.35 & 0.00 & 2.1 \\
\hline 3 & 10.6 & 0.00 & 0.00 & 0.49 & 1.31 & 0.64 & 0.00 & 2.4 & 10.2 & 0.00 & 0.00 & 0.42 & 1.61 & 0.77 & 0.00 & 2.8 \\
\hline 6 & 10.2 & 0.00 & 0.00 & 0.42 & 1.52 & 0.83 & 0.00 & 2.8 & 10.1 & 0.00 & 0.00 & 0.42 & 1.52 & 0.96 & 0.00 & 2.9 \\
\hline 12 & 9.9 & 0.00 & 0.00 & 0.47 & 1.62 & 1.06 & 0.00 & 3.1 & 10.0 & 0.00 & 0.00 & 0.34 & 1.63 & 0.99 & 0.00 & 3.0 \\
\hline 24 & 9.9 & 0.00 & 0.00 & 0.45 & 1.62 & 1.05 & 0.00 & 3.1 & 9.9 & 0.00 & 0.00 & 0.35 & 1.64 & 1.10 & 0.00 & 3.1 \\
\hline
\end{tabular}

production of XOs. In this context, the XOs production by free and immobilized XynA was studied using birchwood xylan as substrate.

XynA is an enzyme that belongs to family 11 of xylanases. Its action and performance are closely related with the composition of the substrate, as shown previously [52]. So, two different substrates were investigated: conventional birchwood xylan and the soluble fraction of the birchwood xylan. The hydrolysis of the two substrates by the action of soluble XynA and agarose-glyoxal-XynA can be seen in Fig. 4.

The results obtained after the measurement of reducing sugars present higher values than those quantified by HPLC. This discrepancy is due to the fact that the quantification of reducing sugars is performed by the DNS method: all reducing terminations that are present, including those of XOs bigger than six monomers and xylooligomers containing ten to hundred of monomeric units, react with 3,5-dinitrosalicilic acid [43]. On the other hand, for the HPLC analysis, the samples were filtered using a $0.22 \mu \mathrm{m}$ membrane in order to retain xylan polymers. The methodology for quantifying XOs by HPLC allows quantifying XOs up to six monomers of xylose, thus justifying the difference observed between the profiles obtained from reducing sugars and using HPLC analyses. However, despite the differences between values, the trends of the curves were similar.

The profiles of the hydrolysis of soluble birchwood xylan conducted using free and immobilized XynA were similar (Fig. 4b and d). The agarose-glyoxal-XynA derivative and the soluble enzyme presented the same conversion of soluble xylan after $3 \mathrm{~h}(20.4$ and $20.6 \%$, respectively), producing $2.8 \pm 0.06 \mathrm{mg} / \mathrm{mL}$ of XOs. A maximum XOs production was reached after $24 \mathrm{~h}$ : for soluble enzyme, $3.1 \pm 0.04 \mathrm{mg} / \mathrm{mL}$ (22.7\% of conversion); and for immobilized enzyme, $3.2 \pm 0.02 \mathrm{mg} / \mathrm{mL}$ (23.5\%). When the soluble xylan was the substrate, both the catalysts (soluble and immobilized enzyme) seem to hydrolyse the substrate with the same velocity. For conventional xylan (i.e. with soluble and solid fractions), after $3 \mathrm{~h}$ of reaction, the agarose-glyoxal-XynA derivative presented a conversion of $13.7 \pm 0.06 \%(1.9 \pm 0.09 \mathrm{mg} / \mathrm{mL}$ of XOs $)$, while the soluble enzyme reached $18.0 \pm 0.1 \%(2.4 \pm 0.1 \mathrm{mg} / \mathrm{mL}$ of XOs $)$. In $24 \mathrm{~h}$, the immobilized enzyme reached $21.5 \pm 0.18 \%$, producing $2.9 \pm 0.03 \mathrm{mg} / \mathrm{mL}$ of XOs and the soluble XynA reached $22.9 \pm 0.25 \%$, producing $3.1 \pm 0.04 \mathrm{mg} / \mathrm{mL}$ of XOs.

The results to the hydrolysis of the soluble xylan, using free and immobilized enzyme, indicate that there is a maximum conversion and, therefore, a maximum XOs production of $3 \mathrm{mg} / \mathrm{mL}$ when $13 \mathrm{mg} / \mathrm{mL}$ of soluble xylan was used as substrate. When $13 \mathrm{mg} / \mathrm{mL}$ of conventional xylan is the substrate, the soluble xylan fraction is only $4.3 \mathrm{mg} / \mathrm{mL}$. Since there is a limit for the action of XynA on birchwood xylan, if only the soluble fraction had been hydrolyzed the maximum expected XOs production would be $0.95 \mathrm{mg} / \mathrm{mL}$. However, the XOs production for conventional xylan is always higher than $0.95 \mathrm{mg} / \mathrm{mL}$ for the two catalysts, soluble and immobilized enzyme. The hydrolysis of conventional birchwood xylan was faster for the free enzyme. This result was expected since a fraction of the insoluble xylan would not be accessible for the immobilized enzyme, at least at the beginning of the process. Despite this fact, our results indicate that the derivative was able to effectively hydrolyze a fraction of the insoluble xylan. Lin et al. [53] observed a more efficient hydrolysis in the XOs production from corncob using endo-xylanases from Bacillus halodurans, free and immobilized on an ion-exchange resin. This work reported a lower yield using the immobilized enzyme and attributed that behavior to the inability of the immobilized enzyme to attack the insoluble fraction. In fact, this phenomenon depends on the molecular size of the xylan and of the support internal structure. In our case, part of the insoluble fraction of birchwood xylan could be hydrolyzed, and the agarose-glyoxal-XynA seems to be a very useful support in this case.

The inability of a pure endoxylanase to completely hydrolyze xylan has been already reported. Akpinar et al. [54] observed a XOs yield of $13.8 \%$ from tobacco stalk xylan using $200 \mathrm{U} / \mathrm{g}$ of xylanase from A. niger at $50^{\circ} \mathrm{C}$ after $24 \mathrm{~h}$. Aragon et al. [7], in the hydrolysis of birchwood xylan $(18 \mathrm{mg} / \mathrm{ml})$, achieved a XOs yield of $13 \%$ using endoxylanase from $A$. versicolor immobilized on agarose-glyoxal at $25^{\circ} \mathrm{C}$ and $\mathrm{pH}$ 5.0. The complete xylan hydrolysis using only endoxylanases, without auxiliary enzymes, is not possible because xylan is not a pure linear polymer of xylose [55].

Birchwood xylan is a glucuronoxylan [55,56] which typically consists of a xylose backbone with 4-methyl- $\alpha$-D-glucuronic acid (MeGa) linked to O-2 of xylose [52]. The side chain of xylan is recognized by xylanases, and these ramifications influence the action of these enzymes [5]. Xylanases from family 11, like $B$. subtilis xylanase, will act only on the xylose immediately before the MeGa-containing xylose [52]. Thus, xylan hydrolysis by a pure endoxylanase has a limiting yield, which depends on the xylan ramifications. In order to achieve total enzymatic breakdown to monomers, de-branching enzymes would be necessary, such as beta-xylosidase (EC 3.2.1.37) and alpha-glucuronidase (EC

Table 3


$\left(13 \mathrm{mg} / \mathrm{mL}, \mathrm{pH} 5.5,50^{\circ} \mathrm{C}\right)$ catalyzed by the agarose-glyoxal-XynA derivative $(1.95 \mathrm{UI} / \mathrm{mL})$.

\begin{tabular}{|c|c|c|c|c|c|c|c|c|c|c|c|c|c|c|c|c|}
\hline \multirow[t]{2}{*}{ Time (h) } & \multicolumn{8}{|c|}{ Conventional xylan(mg/mL) } & \multicolumn{8}{|c|}{ Soluble xylan $(\mathrm{mg} / \mathrm{mL})$} \\
\hline & $\mathrm{X} 7+$ & X6 & $\mathrm{X} 5$ & $\mathrm{X} 4$ & X3 & $\mathrm{X} 2$ & $\mathrm{X} 1$ & Total XOs & $\mathrm{X} 7+$ & $\mathrm{X} 6$ & $\mathrm{X} 5$ & $\mathrm{X} 4$ & X3 & $\mathrm{X} 2$ & $\mathrm{X} 1$ & Total XOs \\
\hline 1 & 11.9 & 0.00 & 0.00 & 0.19 & 0.69 & 0.22 & 0.00 & 1.1 & 11.2 & 0.00 & 0.00 & 0.34 & 1.02 & 0.39 & 0.00 & 1.8 \\
\hline 3 & 11.1 & 0.00 & 0.00 & 0.29 & 0.99 & 0.59 & 0.00 & 1.9 & 10.1 & 0.00 & 0.00 & 0.37 & 1.50 & 1.00 & 0.00 & 2.9 \\
\hline 6 & 10.6 & 0.00 & 0.00 & 0.33 & 1.13 & 0.97 & 0.00 & 2.4 & 10.0 & 0.00 & 0.00 & 0.23 & 1.54 & 1.19 & 0.00 & 3.0 \\
\hline 12 & 10.3 & 0.00 & 0.00 & 0.17 & 1.27 & 1.26 & 0.00 & 2.7 & 9.8 & 0.00 & 0.00 & 0.19 & 1.52 & 1.44 & 0.00 & 3.2 \\
\hline 24 & 10.1 & 0.00 & 0.00 & 0.15 & 1.19 & 1.60 & 0.00 & 2.9 & 9.7 & 0.00 & 0.00 & 0.15 & 1.47 & 1.60 & 0.00 & 3.2 \\
\hline
\end{tabular}



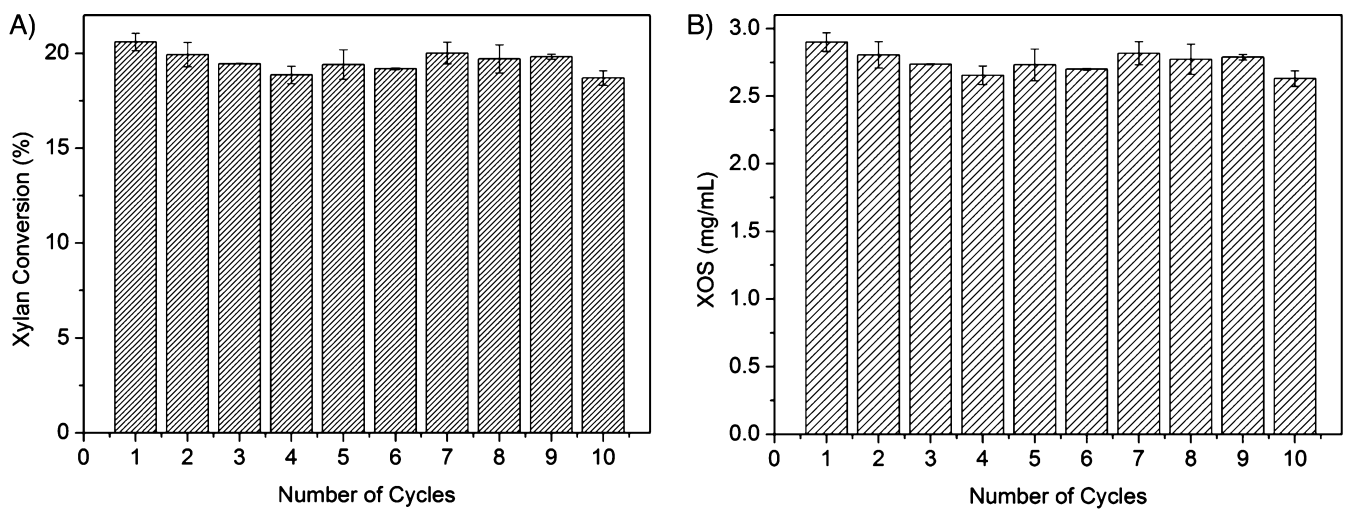

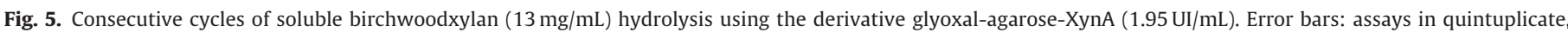
carried out at $50{ }^{\circ} \mathrm{C}$ and $\mathrm{pH} 5.5$.

Table 4

XOs profile obtained from birchwood xylan hydrolysis $\left(15 \mathrm{mg} / \mathrm{mL}, \mathrm{pH} 5.5,50^{\circ} \mathrm{C}\right)$ by XynA soluble and immobilized onto agarose-glyoxal (1.95 UI/mL).

\begin{tabular}{llllll}
\hline \multirow{2}{*}{ Product } & \multicolumn{2}{l}{ Soluble xylan (\%) } & & \multicolumn{2}{l}{ Conventional xylan (\%) } \\
\cline { 2 - 3 } \cline { 5 - 6 } \cline { 5 - 6 } & XynA soluble & XynA derivative & & XynA soluble & XynA derivative \\
\hline X4 & 9.0 & 4.5 & 14.4 & 5.1 \\
X3 & 54.5 & 45.8 & 51.9 & 40.5 \\
X2 & 36.5 & 49.7 & 33.7 & 54.4 \\
\hline
\end{tabular}

3.2.1.139), depending on the composition of the xylan [52]. For XOs manufacturing, however, the production of monomers is not desirable: it is preferable to use a pure endoxylanase, even if a limited conversion is obtained. Thus, the obtained conversions, minimum $21.7 \%$ using conventional birchwood xylan and $23.7 \%$ using soluble xylan, may be considered very good results.

Tables 2 and 3 indicate that the major products obtained in all hydrolysis assays were xylotetraose (X4), xylotriose (X3) and xylobiose (X2), which are the most interesting XOs from the point of view of the food industry. The functional properties of XOs are closely related to their molecular weight distribution, and XOs containing less than four monomers units are considered excellent prebiotics, since they promote efficiently the proliferation of bifidobacteria, which are considered beneficial to the human intestinal micro flora [4]. Thus, the XOs produced by XynA in this study are of excellent quality and have high value added.

The profile of XOs produced by the agarose-glyoxal-XynA derivative was different than the one obtained using the soluble enzyme (Table 4). The soluble enzyme favored the production of xylotriose, which is the main product of the reaction, while using the immobilized xylanase, xylobiose was the major product. Aragon et al. [7], studying the enzymatic breakdown of birchwood xylan $(18 \mathrm{mg} / \mathrm{mL}$ ) by the action of endoxylanases from $A$. versicolor immobilized in glyoxal-agarose, also observed difference between XOs production by soluble and immobilized enzyme, reaching $\mathrm{X} 2$ production two times greater using the immobilized enzyme. This difference in XOs profile can be explained by a possible change in the xylanase conformation due to immobilization, changing catalytic properties that could lead to a different profile of product $[57,58]$. Other explanation may be that the partial products (X4 and $\mathrm{X} 3$ ) are released inside the pores, where they may reach a higher concentration than in the solution. These high concentration of X4 and $\mathrm{X} 3$ inside the support pores can favor a higher hydrolysis level when the immobilized enzyme was used as the catalyst, producing a higher concentration of X2 [18].

XOs purification is a complex problem that entails high costs to the process, since for obtaining food grade XOs different steps of separation and purification are required, mainly when the chemical process is used [4]. The chemical process produces a huge variety of byproducts such as monosaccharides (mainly xylose), acetic acid, furfural and hydroxymethylfurfural, undesirable toxic compounds that hinder the production and use of XOs. Therefore, the enzymatic hydrolysis is the best strategy to food grade XOs production [6]. However, even enzymatic hydrolysis may exhibit byproducts. Aragon et al. [7] reported $10.8 \%$ of xylose when producing XOs from birchwood xylan (1\%) using endo-xylanase from Streptomyces halstedii. Sabina-Hanim et al. [59] observed $25.6 \%$ of xylose in XOs production by xylanase from Trichoderma viride using pretreated palm oil. Brienzo et al. [60], using xylanase from T. aurantiacus on sugarcane bagasse hemicellulose, observed a yield of $12.97 \%$ of xylan after $24 \mathrm{~h}$.

In this study, it is relevant that in all experiments no production of xylose (X1) was observed, since XynA is a strict endo-xylanase, and the host microorganism has not an enzyme able to degrade the xylobiose (X2) formed to xylose. The presence of xylose is undesirable from the point of view of food industry; besides, it can inhibit the enzymatic activity, decreasing the process yield [5]. Hemicellulose hydrolysis using the immobilized XynA was free of by-products process, generating only XOs with a high degree of purity.

\subsection{Immobilized XynA operational stability}

The derivative agarose-glyoxal-XynA is promising for industrial use: it presented an impressive improvement in the thermal stability when compared with the soluble XynA, with a half life of more than eight thousand times higher, and produced XOs, without xylose as co-product. To examine the feasibility of the reuse of immobilized XynA, cycles of soluble xylan hydrolysis catalyzed by agarose-glyoxal-XynA were run. Each cycle lasted $3 \mathrm{~h}$. In the first cycle, a conversion of $20 \%$ was reached after this reaction time, therefore $90 \%$ of the maximum conversion (22\%), with a XOs production of $2.9 \mathrm{mg} / \mathrm{mL}$. Remarkably, after 10 consecutive cycles, the hydrolysis conversion and XOs production remained essentially constant (Fig. 5), with high purity products. Biocatalyst recovery was straight: through a simple and fast filtration step, the biocatalyst could be recovered and used in sequential reactions without losses. This experiment demonstrates the potential of the use of the derivative agarose-glyoxal-XynA for industrial XOs production.

\section{Conclusions}

The hydrolysis of xylan, an abundant polysaccharide in nature, catalyzed by a pure endoxylanase, generates XOs, small oligomers of xylose, a product with a great market. The increase of the thermal stability of the enzyme is important to make the enzymatic industrial process economically viable. A recombinant endoxylanase 
from B. subtillis, XynA, was immobilized and tested for XOs production, aiming at increasing the thermal stability of the enzyme. Three enzyme derivatives were tested, chitosan-glutaraldehyde-XynA, agarose-glyoxal-XynA and chitosan-glyoxal-XynA. They were 1.4fold, 75 -fold and 8600 -fold more stable than the soluble enzyme. The location of lysine residues on the enzyme surface may explain the good results obtained. The agarose-glyoxal derivative was then used to hydrolyze two substrates, conventional birchwood xylan and its soluble xylan fraction. It was demonstrated that the immobilized enzyme could partly hydrolyze both, soluble and insoluble fractions, to a maximum conversion of $23.7 \%$. XynA produced only $\mathrm{X} 2, \mathrm{X} 3$ and $\mathrm{X} 4$, the more valuable XOs, without yielding xylose (which presence would be a drawback for the industrial process). Remarkably, after 10 consecutive cycles of hydrolyses catalyzed by agarose-glyoxal-XynA, the conversion and selectivity with respect to XOs remained essentially unaltered.

\section{Acknowledgments}

The Brazilian authors thank the governmental agencies FAPESP, CNPq and CAPES for the financial support of this work. They also wish to thank ICP for the 22 years of support and fruitful collaboration with our research group.

\section{References}

[1] T. Collins, C. Gerday, G. Feller, FEMS Microbiol. Rev. 29 (2005) 3-23.

[2] M.L. Polizelli, A.C. Rizzatti, R. Monti, H.F. Terenzi, J.A. Jorge, D.S. Amorim, Appl. Microbiol. Biotechnol. 67 (2005) 577-591.

[3] J. Davoodi, W.W. Wakarchuk, P.R. Carey, W.K. Surewicz, Biophys. Chem. 125 (2007) 453-461.

[4] M.J. Vázquez, J.L. Alonso, H. Dominguez, J.C. Parajó, Trends Food Sci. Technol. 11 (2000) 387-393.

[5] A.F.A. Carvalho, P.O. Neto, D.F. Silva, G.M. Pastore, Food Res. Int. 51 (2013) 75-85.

[6] A.A. Achary, S.G. Prapulla, Compr. Rev. Food Sci. 10 (2011) 2-16.

[7] C.C. Aragon, A.F. Santos, A.I. Ruiz-Matute, N. Corzo, J.M. Guisan, R. Monti, C. Mateo, J. Mol. Catal. B-Enzyme 98 (2013) 8-14.

[8] J. Bragatto, F. Segato, F.M. Squina, Ind. Crop. Prod. 51 (2013) 123-129.

[9] M.T. Murakami, R.K. Arni, D.S. Vieira, L. Degrève, R. Ruller, R.J. Ward, FEBS Lett. 579 (2005) 6505-6510.

[10] M.T. Murakami, R. Ruller, R.J. Ward, R.K. Arni, Acta Crystallogr. Struct. Biol. Commun. 61 (2005) 219-220.

[11] R. Ruller, L. Deliberto, T.L. Ferreira, R.J. Ward, Proteins 70 (2008) 1280-1293.

[12] C. Garcia-Galan, A. Berenguer-Murcia, R. Fernandez-Lafuente, R.C. Rodrigues, Adv. Synth. Catal. 353 (2011) 2885-2904.

[13] G.D. Haki, S.K. Rakshit, Bioresource Technol. 89 (2003) 17-34

[14] C. Mateo, J.M. Palomo, G. Fernandez-Lorente, J.M. Guisan, R. Fernandez-Lafuente, Enzyme Microb. Technol. 40 (2007) 1451-1463.

[15] A.C. Godoy, B. de las Rivas, V. Grazú, T. Montes, J.M. Guisán, F. López-Gallego, Biomacromolecules 12 (2011) 1800-1809.

[16] U. Guzik, K. Hupert-Kocurek, D. Wojcieszynska, Molecules 19 (2014) 8995-9018

[17] V. Stepankova, S. Bidmanova, T. Koudelakova, Z. Prokop, R. Chaloupkova, J. Damborsky, ACS Catal. 3 (2013) 2823-2836.

[18] R.C. Rodrigues, C. Ortiz, A. Berenguer-Murcia, R. Torres, R. Fernández-Lafuente, Chem. Soc. Rev. 42 (2013) 6290-6307.

[19] E.T. Hwang, M.B. Gu, Eng. Life Sci. 13 (2013) 49-61.

[20] K. Hernandez, R. Fernandez-Lafuente, Enzyme Microb. Technol. 48 (2011) $107-122$.

[21] D. Brady, J. Jordan, Biotechnol. Lett. 31 (2009) 1639-1650.
[22] P.V. Iyer, L. Ananthanarayan, Process Biochem. 43 (2008) 1019-1032.

[23] K. Martinek, A.M. Klibanov, V.S. Goldmacher, I.V. Berezin, Biochim. Biophys. Acta 485 (1977) 1-12.

[24] A.M. Klibanov, Anal. Biochem. 93 (1979) 1-25.

[25] A.M. Klibanov, Adv. Appl. Microbiol. 29 (1983) 1-28.

[26] C. Mateo, V. Grazú, B.C.C. Pessela, T. Montes, J.M. Palomo, R. Torres, F. López-Gallego, R. Fernández-Lafuente, J.M. Guisán, Biochem. Soc. Trans. 35 (2007) 153-1601.

[27] C. Mateo, J.M. Palomo, M. Fuentes, L. Betancor, V. Grazu, F. López-Gallego, B.C.C. Pessela, A. Hidalgo, G. Fernández-Lorente, R. Fernández-Lafuente, J.M. Guisán, Enzyme Microb. Technol. 39 (2006) 274-280.

[28] V. Grazú, F. López-Gallego, T. Montes, O. Abian, R. González, J.A. Hermoso, J.L. Garcia, C. Mateo, J.M. Guisán, Process Biochem. 45 (2010) 390-398.

[29] C. Mateo, V. Grazu, J.M. Palomo, F. Lopez-Gallego, R. Fernandez-Lafuente, J.M. Guisan, Nat. Protoc. 2 (2007) 1022-1033.

[30] A. Manrich, A. Komesu, W.S. Adriano, P.W. Tardioli, R.L.C. Giordano, Appl. Biochem. Biotechnol. 161 (2010) 455-467.

[31] R. Bernier Jr., M. Desrochers, L. Jurasek, M.G. Paice, Appl. Environ. Microbiol. 46 (1983) 511-514

[32] J. Guisán, Enzyme Microb. Technol. 10 (1988) 375-382.

[33] D.S. Rodrigues, A.A. Mendes, W.S. Adriano, L.R.B. Gonçalves, R.L.C. Giordano, J. Mol. Catal. B Enzyme 51 (2008) 100-109.

[34] I. Aranaz, M. Mengíbar, R. Harris, I. Paños, B. Miralles, N. Acosta, G. Galed, A. Heras, Curr. Chem. Biol. 3 (2009) 203-230.

[35] B. Krajewska, Enzyme Microb. Technol. 35 (2004) 126-139.

[36] O. Barbosa, C. Ortiz, A. Berenguer-Murcia, R. Torres, R.C. Rodrigues, R. Fernandez-Lafuente, RSC Adv. 4 (2014) 1583-1600.

[37] C.R. Silva, T.C. Zangirolami, J.P. Rodrigues, K. Matugi, R.C. Giordano, R.L.C. Giordano, Enzyme Microb. Technol. 50 (2012) 35-42.

[38] M.M. Beppu, E.J. Arruda, R.S. Vieira, N.N. Santos, J. Membr. Sci. 240 (2004) 227-235.

[39] S. Budriene, N. Gorochovceva, T. Romaskevic, L.V. Yugova, A. Miezeliene, G. Dienys, A. Zubriene, Cent. Eur. J. Chem. 3 (2005) 95-105.

[40] W.S. Adriano, D.B. Mendonça, D.S. Rodrigues, E.J. Mammarella, R.L.C. Giordano, Biomacromolecules 9 (2008) 2170-2179.

[41] M.M. Bradford, Anal. Biochem. 72 (1976) 248-254.

[42] T.K. Ghose, V.S. Bisaria, Pure Appl. Chem. 59 (1987) 1739-1752.

[43] G.L. Miller, Anal. Chem. 31 (1959) 426-428.

[44] C. Mateo, O. Abian, M. Bernedo, E. Cuenca, M. Fuentes, G. Fernandez-Lorente, J.M. Palomo, V. Grazu, B.C.C. Pessela, C. Giacomini, G. Irazoqui, A. Villarino, K. Ovsejevi, F. Batista-Viera, R. Fernandez-Lafuente, J.M. Guisán, Enzyme Microb. Technol. 37 (2005) 456-462.

[45] L. Cong, T. Tianwei, Z. Haiyang, F. Wei, J. Biol. Chem. 285 (2010) 28434-28441.

[46] R.S. Vieira, M.M. Beppu, Colloids Surf A 279 (2006) 196-207.

[47] C.C. Aragon, C. Mateo, A.I. Ruiz-Matute, N. Corzo, G. Fernandez-Lorente, L. Sevillano, M. Díaz, R. Monti, R.I. Santamaría, J.M. Guisan, Process Biochem. 48 (2013) 478-483.

[48] A.R.L. Damásio, T.M. Silva, F.B.R. Almeida, F.M. Squina, D.A. Ribeiro, A.F.P. Leme, F. Segato, R.A. Prade, J.A. Jorge, H.F. Terenzi, M.L.T.M. Polizeli, Process Biochem. 46 (2011) 1236-1242.

[49] A. Schellenberger, R. Ulbrich, Biomed. Biochim. Acta 48 (1989) 63-67.

[50] A. Manrich, C. Galvao, C. Jesus, R.C. Giordano, R.L.C. Giordano, Int. J. Biol Macromol. 43 (2008) 54-61.

[51] F.F. Furlan, C.B.B. Costa, G.C. Fonseca, R.P. Soares, A.R. Secchi, A.J.G. Cruz, R.C. Giordano, Comput. Chem. Eng. 43 (2012) 1-9.

[52] D. Dodd, I.K.O. Cann, GCB Bioenergy 1 (2009) 2-17.

[53] Y. Lin, M. Teng, W. Lee, Process Biochem. 46 (2011) 2117-2121.

[54] O. Akpinar, K. Erdogan, S. Bostanci, Carbohydr. Res. 344 (2009) 660-666.

[55] J. Zhang, M. Siika-Aho, T. Puranen, M. Tang, M. Tenkanen, L. Viikari, Biotechnol. Biofuels 4 (2011) 1-12.

[56] V. Saraswat, V.S. Bisaria, Biosci. Biotechnol. Biochem. 64 (2000) 1173-1180.

[57] S. Romo-Sanchez, C. Camacho, H.L. Ramirez, M. Arévalo-Villena, Adv. Biosci. Biotechnol. 5 (2014) 517-526.

[58] R.K. Singh, M.K. Tiwari, R. Singh, J. Lee, Int. J. Mol. Sci. 14 (2013) 1232-1277.

[59] S. Sabiha-Hanim, M.A.M. Noor, A. Rosma, Bioresour. Technol. 102 (2011) 1234-1239.

[60] M. Brienzo, W. Carvalho, A.M.F. Milagres, Appl. Biochem. Biotechnol. 162 (2010) 1195-1205 